\title{
Short Communication \\ Antibacterial activity of Baccharis trimera (Less.) DC. (carqueja) against bacteria of medical interest ${ }^{1}$
}

\author{
Álan Alex Aleixo², Karina Marjorie Silva Herrera ${ }^{3}$, Rosy Iara Maciel de Azambuja Ribeiro ${ }^{4}$, \\ Luciana Alves Rodrigues dos Santos Lima ${ }^{5}$, Jaqueline Maria Siqueira Ferreira ${ }^{6}$
}

\begin{abstract}
Baccharis trimera (Less.) (Asteraceae), popularly know as "carqueja”, is a species commonly used in folk medicine for the treatment or prevention of diseases. In this context, the purpose of this work was to study the antibacterial activity of crude hydroalcoholic extract from Baccharis trimera against Gram-positive bacterial strains (Staphylococcus aureus ATCC 29213, Staphylococcus saprophyticus ATCC 15305, Staphylococcus epidermidis ATCC 12228, Enterococcus faecalis ATCC 19433) and Gram-negative bacteria (Escherichia coli EHEC ATCC 43895, Pseudomonas aeruginosa ATCC 27853, Klebsiella pneumoniae ATCC 27736, Salmonella typhi ATCC 19430) of clinical interest. Antibacterial susceptibility was evaluated by broth microdilution assay following the CLSI (formerly the NCCLS) guidelines. The extract from $B$. trimera showed antibacterial activity against Gram-positive bacteria and the most interesting result was obtained against $S$. epidermidis that presented Minimal Inhibitory Concentration of $250 \mu \mathrm{g} / \mathrm{mL}$. These results indicate that $B$. trimera have bacterisostatic potential against Gram-positive bacterial strains of medical interest and could serve as a base for further studies on the use of isolated compounds from this species as future antimicrobials.
\end{abstract}

Key words: antimicrobial agents, Baccharis trimera, Staphylococcus epidermidis, minimal inhibitory concentration.

\section{RESUMO}

\section{Avaliação antibacteriana de Baccharis trimera (Less.) DC. (carqueja) em bactérias de interesse médico}

Baccharis trimera (Less.) (Asteraceae), popularmente conhecida como "carqueja”, é uma espécie comumente empregada na medicina tradicional no tratamento ou prevenção de doenças. Nesse contexto, o objetivo deste trabalho foi estudar a atividade antibacteriana do extrato bruto hidroalcoólico de B. trimera frente às bactérias Gram-positivas (Staphylococcus aureus ATCC 29213, Staphylococcus saprophyticus ATCC 15305, Staphylococcus epidermidis ATCC 12228, Enterococcus faecalis ATCC 19433) e bactérias Gram-negativas (Escherichia coli EHEC ATCC 43895, Pseudomonas aeruginosa ATCC 27853, Klebsiella pneumoniae ATCC 27736 e Salmonella typhi ATCC 19430) de interesse clínico. A susceptibilidade antibacteriana foi avaliada pelo método de microdiluição em caldo conforme estabelecido pelo CLSI (antigo NCCLS). O extrato de B. trimera mostrou atividade contra bactérias Gram-positivas, sendo o resultado mais interessante o obtido por $S$. epidermidis, que apresentou Concentração Inibitória Mínima de

\footnotetext{
Received: 05/12/2012; Accepted: 29/08/2013.

${ }^{1}$ Extracted from the first author scientific report presented to FAPEMIG/UFSJ

${ }^{2}$ Undergraduate of Biochemistry. Laboratório de Microbiologia, Universidade Federal de São João Del-Rei, Campus Centro Oeste Dona Lindu, Rua Sebastião Gonçalves Coelho, 400, Bairro Chanadour, 35501-296, Divinópolis, Minas Gerais, Brazil. aleixocn@ hotmail.com

${ }^{3}$ Biologist, Master of Science. Laboratório de Microbiologia, Universidade Federal de São João Del-Rei, Campus Centro Oeste Dona Lindu, Rua Sebastião Gonçalves Coelho, 400, Bairro Chanadour, 35501-296, Divinópolis, Minas Gerais, Brazil. kmsherrera@gmail.com

${ }^{4}$ Biologist, Doctor of Science. Laboratório Biologia Celular e Cultura de Células, Universidade Federal de São João Del-Rei, Campus Centro Oeste Dona Lindu, Rua Sebastião Gonçalves Coelho, 400, Bairro Chanadour, 35501-296, Divinópolis, Minas Gerais, Brazil. rosyiara@gmail.com

${ }^{5}$ Pharmacist, Doctor of Science. Laboratório de Farmacognosia, Universidade Federal de São João Del-Rei, Campus Centro Oeste Dona Lindu, Rua Sebastião Gonçalves Coelho, 400, Bairro Chanadour, 35501-296, Divinópolis, Minas Gerais, Brazil. lucianaarsantos@yahoo.com.br

${ }^{6}$ Biologist, Doctor of Science. Laboratório de Microbiologia, Universidade Federal de São João Del-Rei, Campus Centro Oeste Dona Lindu, Rua Sebastião Gonçalves Coelho, 400, Bairro Chanadour, 35501-296, Divinópolis, Minas Gerais, Brazil. jaque@ufsj.edu.br (corresponding author).
} 
$250 \mu \mathrm{g} / \mathrm{mL}$. Esses resultados indicam que $B$. trimera possui potencial atividade bacteriostática contra bactérias Grampositivas de interesse médico e podem apresentar subsídios para estudos posteriores do uso de compostos isolados dessa espécie como futuros agentes antimicrobianos.

Palavras-chave: agentes antimicrobianos, Baccharis trimera, Staphylococcus epidermidis, concentração inibitória mínima.

\section{INTRODUCTION}

Baccharis trimera (Less.) (Asteraceae) is a common species in the tropical regions of South America. Decoction of the aerial parts of this plant are traditionally used for the treatment or control of various diseases (de Oliveira Jr et al., 2012). In vitro assays on the antimicrobial activity of the decoct of aerial parts of $B$. trimera showed activity against Gram-positive samples of Staphylococcus aureus and Streptococcus uberis (Avancini \& Mundstock, 2000). Moreover, the synergism between the combination of methanol extract from the plant and some antibiotics inhibitors of bacterial protein synthesis has been reported against Staphylococcus aureus (Betoni et al., 2006).

The increase in resistant and multi-resistant strains to the antimicrobials available in the market along with the sustainable production and the search for low-side effect drugs have been contributed to the search for alternative treatments against diseases caused by microorganisms (Clardy et al. 2006; OMS, 2010; Jorgetto et al., 2011). The increased resistance occurs as a response of human activity, especially the overuse of antibiotics and also by the natural adaptation that these microorganisms acquire in the environment (Josephson, 2006). Nosocomial infections caused by strains resistant to available antibiotics by the pharmaceutical industry are a serious public health problem whose impact is worldwide, which makes the search for new antimicrobial agents extremely important (Pereira et al., 2013).

Thus, the present study aimed at studying the in vitro antibacterial activity of crude hydroalcoholic extract from B. trimera against Gram-positive and Gram-negative bacteria causative of nosocomial infections.

\section{MATERIALS AND METHODS}

\section{Plant material}

Aerial parts of $B$. trimera were collected in a periphery neighborhood of São Sebastião do Oeste, Minas Gerais, located in the coordinates $-20^{\circ} 14^{\prime} 38.96^{\prime \prime} \mathrm{S}$ and $-45^{\circ} 2^{\prime}$ 14.38"W, with altitude of 712 meters, in August 2011. The voucher specimen was deposited at the Herbarium of the Instituto de Ciências Biológicas, Universidade Federal de Minas Gerais, Belo Horizonte, MG, Brazil (BHCB 159398).

Aerial parts of $B$. trimera $(172.44 \mathrm{~g})$ were used for extraction by cold maceration $(20 \% \mathrm{p} / \mathrm{v})$ in ethanol P.A
(Vetec, Brazil). After incubation, the extract was filtered and concentrated in a rotary evaporator at $40^{\circ} \mathrm{C}$ under reduced pressure to yield the ethanol extract. The dried extract $(4.79 \mathrm{~g})$ was obtained after lyophilization (Liobras equipament, model $\mathrm{K} 105$ ) and stored at $-70^{\circ} \mathrm{C}$.

\section{Determination of the Minimal Inhibitory Concentration and Minimum Lethal Concentration (MLC)}

The Minimal Inhibitory Concentration (MIC) was determined using the broth microdilution method performed in accordance with the guidelines of the Clinical and Laboratory Standards Institute (CLSI M7-A6 document, 2003). Four Gram-negative bacteria (Escherichia coli EHEC American Type Culture Colletion (ATCC) 43895, Pseudomonas aeruginosa ATCC 27853, Klebsiella pneumoniae ATCC 27736 and Salmonella typhi ATCC 19430) and four Gram-positive bacteria (Staphylococcus aureus ATCC 29213, Staphylococcus saprophyticus ATCC 15305, Staphylococcus epidermidis ATCC 12228 and Enterococcus faecalis ATCC 19433) were used in the biological assays. The bacterial strains were kindly provided by the Reference Microorganisms Laboratory of the Oswaldo Cruz Foundation, FIOCRUZ/ Brazil.

The extract was diluted in sterile dimethylsulfoxide (DMSO) 20\% to the concentrations $1.25 ; 1.0 ; 0.50 ; 0.500$; 0.250 and $0.125 \mathrm{mg} / \mathrm{mL}$ for antimicrobial tests. Streptomycin (Sigma-Aldrich, USA) and DMSO (Sigma, USA) were included as positive and negative controls, respectively. The MIC was assessed based on the lowest concentration of sample required to inhibit microbial growth (detected as the lack of visible turbidity). The experiments were performed in triplicate and repeated three times.

For assays to determine the Minimum Lethal Concentration (MLC), aliquots of $25 \mu \mathrm{L}$ were removed from wells without visible turbidity and placed on Agar Platecount using the Spread-plate Method. After incubation at $37^{\circ} \mathrm{C}$ for $24 \mathrm{~h}$, colonies were counted. The concentration of sample that resulted in a growth $0.1 \%$ of initial inoculum $\left(1.510^{6} \mathrm{UFC} / \mathrm{mL}\right)$ was determined as the MLC.

\section{Statistical analyses}

Analyses were performed by median values of absorbance using the variance test followed by the Tukey test $(\mathrm{p}<0.05)$. 


\section{RESULTS AND DISCUSSION}

The crude hydroalcoholic extract from $B$. trimera showed antibacterial activity against four bacterial strains with $100 \%$ of inhibition of Gram-positive bacteria. S. epidermidis was the specie that presented the best sensibility, MIC $250 \mu \mathrm{g} / \mathrm{mL}$. The bacterial strains E. faecalis and S. aureus showed MIC $500 \mu \mathrm{g} /$ $\mathrm{mL}$ and $S$. saprophyticus was the more resistant species, with MIC of $1250 \mu \mathrm{g} / \mathrm{mL}$ (Table 1). On the other hand, Gram-negative strains did not show sensibility to the B. trimera extract in the concentrations tested (MIC $>1250 \mu \mathrm{g} / \mathrm{mL}$ ). Streptomicin, used as positive control, presented MIC between 3.9 and $62.5 \mu \mathrm{g} / \mathrm{mL}$. No activity was observed for the negative control (DMSO 2\%) (Table 1). The extract showed no bactericidal activity (data not show).

The results of this work demonstrate that the crude hydroalcoholic extract from $B$. trimera has selective action against the biochemical structure of the bacterial cell wall, being mainly active against Gram-positive bacteria. In this respect, similar results were described in which Grampositive bacteria were more sensitive when tested with the decoct of $B$. trimera after Galenic extraction, confirming the selective character of the extract or its compounds (Avancini \& Mundstock, 2000).

Although there is no literature explaining the relationship between the microbial sensitivity to extracts and structure of bacterial cells, some authors suggest that the effectiveness of inhibitory action of the extracts on bacteria, both Gram-positive and Gram-negative bacteria, may be associated to the peculiarities of the extract composition on the cellular constitution of microorganisms. The activity of certain substances of the plant may be related to the efficacy observed in Grampositive bacteria, since they exhibit chemically less complex cell wall, less lipid content and lack of outer cell membrane compared to the Gram-negative bacteria (Deans \& Ritchie, 1987; Srinivasan et al., 2001).

The presence of diterpenes and flavonoids in plants of the genus Baccharis may explain, at least in part, the antibacterial activities observed. Several compounds isolated from these two classes of secondary metabolites have been reported with activity against Gram-positive Staphylococcus sp (Tsukiyama et al., 2002; Ulubelen, 2003).

Our results show that bacteria belonging to the genera Staphylococcus and Enterococcus are more sensitive to the extract of $B$. trimera or its components. In view of the clinical importance of the microorganisms belonging to these genera, the present results encourage further studies in order to isolate and characterize compounds and antimicrobial properties of this species, considering that MIC below $1000 \mu \mathrm{g} / \mathrm{mL}$ for plant crude extract represents the possibility of isolates with better activity and higher antimicrobial specificity.

Table 1. Minimal inhibitory concentration (MIC) of hidroalcoholic extracts of Baccharis trimera (Less) against Gram-positive and Gram-negative bacteria of clinical interest

\begin{tabular}{lcc}
\multirow{2}{*}{ Bacteria (ATCC) } & \multicolumn{2}{c}{$\mathbf{M I C}(\boldsymbol{\mu g} / \mathbf{m L})$} \\
\cline { 2 - 3 } Gram-positive & Crude extract of $\boldsymbol{B . ~ t r i m e r a}$ & Streptomycin \\
\hline Staphylococcus epidermidis $(12228)$ & & 3,9 \\
Staphylococcus aureus $(29213)$ & 500 & 3,9 \\
Enterococcus faecalis $(19433)$ & 500 & 62,5 \\
Staphylococcus saprophyticus $(15305)$ & 1250 & 1,95 \\
\hline Gram-Negative & & 3,9 \\
\hline Klebsiella pneumoniae $(27736)$ & $>1250$ & 7,81 \\
Salmonella typhi $(19430)$ & $>1250$ & 3,9 \\
Escherichia coli EHEC $(43895)$ & $>1250$ & 7,81 \\
Pseudomonas aeruginosa $(27853)$ & $>1250$ & \\
\hline
\end{tabular}

\section{CONCLUSIONS}

The minimal inhibitory concentrations from hidroalcoholic extracts of $B$. trimera ranged between 250 to $1250 \mu \mathrm{g} / \mathrm{mL}$ in Gram-positive bacteria. However, no activity was observed in Gram-negative strains. The results showed that $B$. trimera have an antimicrobial potential against Gram- positive strains, becoming an important alternative for prospection of new molecules with antibiotic properties.

\section{ACKNOWLEDGMENTS}

This work was supported by grants from FAPEMIG, CNPq and UFSJ.

Rev. Ceres, Viçosa, v. 60, n.5, p. 731-734, set/out, 2013 


\section{REFERENCES}

Avancini CAM, Wiest JM \& Mundstock E (2000) Atividade bacteriostática e bactericida do decocto de Baccharis trimera (Less) DC, Compositae, carqueja, como desinfetante ou antiséptico. Arquivo Brasileiro de Medicina Veteriária e Zootecnia, $52: 230-234$

Betoni JEC, Mantovani RP, Barbosa LN, Di Stasi LC \& Junior AF (2006) Synergism between plant extract and antimicrobial drugs used on Staphylococcus aureus diseases. Memórias do Instituto Oswaldo Cruz, 101:387-390.

Clardy J, Fischbach MA \& Walsh CT (2006) New antibiotics from bacterial natural products. Nature Biotechnology, 24:15411550 .

Clinical Laboratory Standards Institute (2003) Methods for Dilution Antimicrobial Susceptibility Tests for Bacteria That Grow Aerobically. CLSI document M7- A6. Wayne, PA. 23:1-49.

de Oliveira Jr CJF, Cabreira PP \& Begossi A (2012) The Dilemma of Plant Knowledge and Compensation for Native People Living in Brazilian Biomes. Journal of Ecosystem \& Ecography, 2:1-5.

Deans SG \& Ritchie G (1987) Antibacterial properties of plant essential oils. International journal of food microbiology, 5:165-180.

Jorgetto GV, Boriolo MFG, Silva LM, Nogueira DA, José TDS, Ribeiro GE, Oliveira NMS \& Fiorini JE (2011) Analysis on the in vitro antimicrobial activity and in vivo mutagenicity by using extract from Vernonia polyanthes Less (Assa-peixe). Revista do Instituto Adolfo Lutz, 70:53-61.
Josephson J (2006) The microbial "resistome". Environmental science \& technology, 40:6531-6534.

Organização Mundial de Saúde (2000) Vencendo a resistencia microbiana. Available at: http://www.ccih.med.br/vencendoresistencia.html. Accessed on: August 08, 2012.

Pereira CAP, Marra AR, Camargo LFA, Pignatari ACC, Sukiennik T, Behar PRP, Medeiros EAS, Ribeiro J, Girão E, Correa L, Guerra C, Carneiro I, Brites C, Reis M, Souza MA, Tranchesi R, Barata CU, Edmond MB (2013) Nosocomial Bloodstream Infections in Brazilian Pediatric Patients: Microbiology, Epidemiology, and Clinical Features. PLoS One, 8: e68144.

Srinivasan D, Nathan S, Suresh T \& Lakshmana Perumalsamy P (2001) Antimicrobial activity of certain Indian medicinal plants used in folkloric medicine. Journal of Ethnopharmacology, 74:217-220.

Tsukiyama RI, Katsura H, Tokuriki N \& Kobayashi M (2002) Antibacterial activity of licochalcone A against spore-forming bacteria. Antimicrobial Agents and Chemotherapy, 46:12261230 .

Ulubelen A (2003) Cardioactive and antibacterial terpenoids from some Salvia species. Phytochemistry, 64:395-399. 